\title{
The Concept of the Fetish
}

The term fetishism suits quite well, we think, this type of sexual perversion. The adoration, in these illnesses, for inanimate objects such as night caps or high heels corresponds in every respect to the adoration of the savage or negro for fish bones or shiny pebbles, with the fundamental difference, that in the first case religious adoration is replaced by sexual appetite.

—Alfred Binet, "Le fétichisme"

If what we now term fetishes brought European and African men together in the 2oros, it was hardly for the first time. Atlantic Africa was, in fact, the scene for the creation of the very idea of the fetish.

In a series of remarkable essays, William Pietz (1985, 1987, 1988) laid out an intellectual history of the interaction of Portuguese and then Dutch, English, and other European traders with Atlantic Africans after the fifteenth century. Accounts of European voyages to Africa, such as the one published in 1703 by Dutch merchant Willem Bosman, A New and Accurate Description of the Coast 
of Guinea, found their way into the libraries of some of the most prominent European intellectuals. ${ }^{.}$By the time of the Enlightenment, the idea of the fetish provided Europeans with a potent example of just what reason was not-hence Hegel's (in)famous account of the lack of dialectical development in African history.

By the latter half of the nineteenth century, it was becoming clear that the concept of the fetish had little relation to the complexities of West African belief; even so, what Masuzawa (2000) called the ghost of fetishism continued to animate theoretical conversation. Not long afterward, the idea of the fetish had all but died in anthropology, but it had a dramatic rebirth in analyses of Europe itself, after Marx and later the sexologists like Binet, Krafft-Ebing, and Freud imported the idea to describe, respectively, the formation of capitalist economies and European psyches.

For Marx, the fetish of commodities or money-or at the deepest level, capital-involved a misattribution of the power and creativity of human labor to mere things. In capitalism, men and women produce an ever-expanding array of wealth, but ironically, they experience the very things they create as having power over them. Consequently, they bow down and worship the fetish (capital). We say that money makes money and that capital creates.

For Freud, fetishism also involved a displacement from "reality," but the primal story he told involved not the shape of world history but the contours of individual development. The "end pleasure" of reproductive sex (Freud [1925] 2000, 76) could be blocked by an attachment to fetishes - for example, fur or underwear (instead of genitals). ${ }^{2}$ The master fetish, it might be thought, would be the father's phallus, but according to Freud, it was actually the mother's. Or more correctly, it was the "disavowal" that the mother lacked a phallus.3 "Monuments, it was 
once suggested, are to history as the fetish is to the maternal phallus. In order to deny the absence of something that doesn't exist, you fill the gap, blanking out the absence and endowing this material object [the fetish] with the lineaments of your desire" (Ades 1995, 85).

The fetishistic situation involved, then, a little boy's anxiety that he himself might suffer "castration." Bowing down to a sexual fetish was a way of dealing with the unease, ${ }^{4}$ but it was one that could also prevent the boy from finally commanding the power of the phallus and taking his father's place.

Both the sexual scientists and Marx had enormous influence, far beyond intellectuals. Marx's Capital, published in I867 and subsequently translated into many of the world's languages, was one of the nineteenth century's most influential texts, made sacred by early twentieth-century socialist regimes. It set out a historical teleology that promised a final salvation, communism, based not just on liberating individual consciousnesses but on changing the structure of society through social revolution.

Exactly how and when that teleology ceased to be credible to most of the world's population is a story that remains to be plumbed, but certainly after the disintegration of the Soviet Union in 1989 , its demise was clear for almost all to see (BuckMorss 2000; Furet [1995] 1999). The collapse of Marxist teleology was, according to Jean-François Lyotard ([1979] 1984), only one instance of a larger cultural pattern in which all "metanarratives" no longer make sense. In our so-called postmodern age, the allure of commodities became something to be celebrated. Advertisers self-consciously specialized in the propagation of fetishes, and artists like Andy Warhol attempted to capture their magic. 
To turn from Marx to the sexologists, Binet is remembered today more for his role in intelligence testing than in relation to theories of sex, but, in fact, he was the first to apply the notion of the fetish to the sexual realm. In his i 887 article, "Le fétichisme dans l'amour," Binet summarized a case described five years earlier by his teacher, Charcot. ${ }^{6}$ The case of the eroticized nightcap was then repeated by Krafft-Ebing in his $P s y$ chopathia Sexualis:

L., aged thirty-seven, clerk, from tainted family, had his first erection at five years, when he saw his bed-fellow — an aged relativeput on his night-cap. The same thing occurred later, when he saw an old servant put on her night-cap. Later, simply the idea of an old, ugly woman's head, covered with a night-cap, was sufficient to cause an erection. The sight of a cap or of a naked woman or man only made no impression, but the mere touch of a night-cap induced erection, and sometimes even ejaculation. L. was not a masturbator, and had never been sexually active until his thirty-second year, when he married a young girl with whom he had fallen in love. On his marriage-night he remained cold until, from necessity he brought to his aid the memory-picture of an ugly woman's head with a night-cap. Coitus was immediately successful. Thereafter it was always necessary for him to use this means. Since childhood he had been subject to occasional attacks of depression, with tendency to suicide, and now and then to frightful hallucinations at night. When looking out of a window, he became dizzy and anxious. He was a perverse, peculiar, and easily embarrassed man, of bad mental constitution. (Krafft-Ebing [1902] 1965, 175-76)

Krafft-Ebing's work went through seventeen editions from I886 to 1924 , with numerous translations from German into other languages. Freud's Three Essays on the Theory of Sexuality subsequently went through six German editions from 1905 to 1925 , with even more translations. 
Many ordinary readers found in Krafft-Ebing's and Freud's works insights into their deepest selves (Oosterhuis 1997). What had seemed in some cases a vaguely felt but indistinct sense of difference, or in others a deep and lonely secret, came now to be publicly named and described by medical authority? For example, Samuel Steward, growing up in rural Ohio in the rozos, discovered British sexologist Havelock Ellis's Sexual Inversion in his late teen years. According to Steward's biographer, Justin Spring:

The book immediately set Steward's mind at ease about just who and what he was, and proved a welcome alternative to the vague but terrifying sermons he had heard all through childhood about "sexual sin." Thanks to Ellis, "not only did I discover that I was not insane or alone in a world of heteros-but I also learned many new things to do. I made a secret hiding place for the book under the attic stairs, and read and read and read. Thus I became an expert in the field of sex theory (by the time I finished the book I probably knew more about sex than anyone else in the county) and then began to make practical applications of this vast storehouse of materials." (Spring 20I0, IO-II)

Deviations, at least in their most pronounced forms, were diseases according to many early sexologists, but what made sexual fetishes pathologies depended entirely on the assumption that the telos of sex is biological reproduction (see Davidson 1987, 259-62). When that assumption, like other teleologies, no longer made sense to many Europeans and North Americans, the pathology of sexual fetishes began to fall away. ${ }^{8}$ The cultural transformation was hardly complete or uncontested, of course, but just the same, it was dramatic. Homosexuality became more or less a benign variation. And even sadomasochism became something of a cultivated art, a kind of postmodern ars erotica - at least in certain limited circles in San Francisco and New York, Amsterdam and Berlin.? 